\title{
CAUSES OF SCHOOL DROPOUTS AMONG CONGOLESE MUSLIM REFUGEES IN KATWE, KAMPALA, UGANDA
}

\author{
Mwisha Chinyabuuma ${ }^{1 *}$, Amika A Wardana ${ }^{2}$, Muhammad Abbas ${ }^{3}$ \\ ${ }^{1}$ Research Centre and Community Development of the Uplift a Child, Kampala, Uganda, e-mail: dieumedechy@gmail.com \\ ${ }^{2}$ Yogyakarta State University, Yogyakarta, Indonesia, e-mail: a.wardana@uny.ac.id \\ ${ }^{3}$ Yogyakarta State University, Yogyakarta, Indonesia,e-mail:mubamadabbas@hotmail.com \\ *Corresponding Author
}

\section{(c) (i) (2)}

C)2020 by the authors. Submitted for possible open access publication under the terms and conditions of the Creative Commons Attribution-ShareAlike 4.0 International License-(CC-BY-SA) (https://creativecommons.org/licenses/by-sa/4.0/) do DOI http://dx.doi.org/10.30983/islam realitas.v6i1.3233

\begin{tabular}{l|l|l} 
Submission: 28 April 2020 & Revised: 28 June 2020 & Published: 30 June 2020
\end{tabular}

\begin{abstract}
This study aims to examine whether language barriers, early marriage, and underfunding lead to school dropouts among Congolese Muslim refugees in Katwe, Uganda, East Africa. This research was motivated by the problems faced by students in refugee areas in general, especially the problem of dropping out of school. Dropping out of school fundamentally affects the future of refugee children as this situation tends to lead to early marriages, drug use, manual labor, and prostitution. This study uses a quantitative approach using a questionnaire distributed to student respondents who dropped out of school among the Congolese Muslim refugees. In addition, this study also uses a qualitative approach by conducting observations and interviews. The results of this study indicate that language barriers in the refugee camps, early marriage and lack of living expenses are the main causes of dropping out of school among the Congolese Muslim refugee youth in Katwe. This study also notably finds that language barriers in refugee camps are the most influential factor in the real-life challenges faced by refugees.
\end{abstract}

Keywords: School dropout; Katwe refugees camp; Barriers.

\begin{abstract}
Abstrak
Penelitian ini bertujuan untuk menguji apakah hambatan bahasa, pernikahan dini dan kekurangan biaya yang menyebabkan putus sekolah pada pengungsi Muslim Kongo di Katwe, Afrika Timur. Riset ini dilatarbelakangi oleh permasalahan pelajar di wilayah pengungsian pada umumnya, terutama putus sekolah. Putus sekolah secara fundamental mempengarubi masa depan anak-anak pengungsi karena situasi ini cenderung mendorong anak ke pernikahan dini, penggunaan obat-obatan terlarang, pekerjaan kasar, dan prostitusi. Penelitian ini menggunakan pendekatan kuantitatif dengan menggunakan angket yang disebarkan pada responden pelajar putus sekolah pada pengungsi Muslim Kongo, di samping itu penelitian ini juga menggunakan pendekatan kualitatif dengan melakukan observasi dan wawancara. Hasil penelitian ini menunjukkan bahwa kendala bahasa di wilayah tempat pengungsi, pernikahan dini serta kekurangan biaya bidup menjadi penyebab utama banyak kalangan remaja pengungsi muslim Kongo di Katwe mengalami putus sekolah. Temuan menarik dan lebih spesifik adalah kendala bahasa di tempat pengungsian menjadi faktor yang paling berpengaruh di tengah tantangan kehidupan nyata yang dihadapi oleh para pengungsi.
\end{abstract}

Kata Kunci: Putus sekolah; Pengungsi kamp Katwe; Hambata

\section{Background}

According to UNESCO studies and international conferences on education, school completion rates have steadily increased over the past 50 years due to better accessibility ${ }^{12}$. However, dropping out of school continues to be a significant problem that interferes with young people's education. In the case of Africa, various socio-economic and political issues, as well as high levels of poverty, have been the main cause for this high dropout rate. ${ }^{3}$

One of the major issues emerging from UNESCO's 2012 Global Education Digestive
1 Alison Earle, Natalia Milovantseva, and Jody Heymann, 'Is Free Pre-Primary Education Associated with Increased Primary School Completion? A Global Study', International Journal of Child Care and Education Policy, 12.1 (2018), 13.

${ }^{2}$ Daniel A Wagner, "What Happened to Literacy? Historical and Conceptual Perspectives on Literacy in
UNESCO', International Journal of Educational Development, 31.3 (2011), 319-23.

${ }^{3}$ Michaela C. Pascoe, Sarah E. Hetrick, and Alexandra G. Parker, 'The Impact of Stress on Students in Secondary School and Higher Education', International Journal of Adolescence and Youth, 25.1 (2020), 104-12 <https://doi.org/10.1080/02673843.2019.1596823>. 
Study is the global dropout levels that do not seem to be decreasing over the years. High numbers of students are dropping out of school worldwide. The high school dropout rate in the United States in 2009 was $8.1 \% .^{4}$ In the developing world, the high school dropout level is particularly high. In South and West Asia, 33 of every 100 pupils in primary school will leave before they enter the final grade; while in Latin America and the Caribbean, 17\% of pupils leave school before they complete primary education. Sub-Saharan Africa has the highest dropout rate with $42 \%$ of its pupils leaving school early. ${ }^{5}$

According to the 2009 UNHCR study on education, Kenya has a lower dropout rate compared to Uganda, but higher than Tanzania's. ${ }^{6}$ According to a report by the United Nations Educational, Scientific and Cultural Organization, Uganda has the highest dropout rate in East Africa. ${ }^{7}$ This means that Uganda still has the lowest proportion of children staying in school up to Primary Seven.

In a separate study by the Ugandan Government, half of the pupils enrolled in Primary One do not complete Primary Seven in the average timeframe. For example, statistics at the Ministry of Education indicate that last year, of the 890,997 who enrolled in 2003, only 444,019 pupils sat for the Primary Leaving Examination. Therefore, a total of 446,978 either dropped out or had to repeat a grade. Ministry of Education data shows that school dropouts are higher at the primary than at the secondary level. Previous studies demonstrate that lack of interest, pregnancy, early marriages, hidden school costs, and family responsibilities

${ }^{4}$ Christine Mbabazi Mpyangu, et.al., 'Out of School Children Study in Uganda', Paper (Kampala, 2014) <https://doi.org/10.1016/j.jiec.2016.01.036>.

${ }^{5}$ Global Partnership for Education, Results Report 2019 (Washington D.C, 2019).

${ }^{6}$ Ricardo Sabates and others, 'School Drop out: Patterns, Causes, Changes and Policies', Paper prepared by the Centre for International Education School of Education and Social Work University of Sussex, July 2010. are factors that drive thousands of students out of school. ${ }^{8}$

When it comes to forced migrants, dropout from school is a serious problem that has not to be addressed by the asylum country. This is due to structural oppression, language barriers, and other factors related to the trauma of the war. Congolese refugees are struggling to integrate into their new world in Kampala. In this circumstance, the language gap has been a key problem preventing integration. This means that they fail to communicate with local Ugandans, making it difficult to perform simple day-to-day transactions. This condition has had a detrimental impact on the education of young Congolese refugees, indicated by their high dropout rates. ${ }^{9}$

However, In Katwe, the home of the majority of Congolese refugees, the enrolment level is very high in the primary school level because of the easier adaptation of the language. It is natural that primary school students could easily acquire and learn a new language. However, this does not apply to secondary school students, even after they have undergone intensive English training offered by charity organizations. The high rate of dropouts is seen among primary pupils before reaching grade seven; for the few secondary students enrolled only two out of the ten would finish their A level. $^{10}$

Almost three out of every five students drop out before completing their primary or high school level. According to research conducted by refugee charity organizations in Kampala, the high level of school dropout is

${ }^{7}$ WHO Team, 'Adolescent Pregnancy', Report (Washington D.C., 2020).

8 WHO Team.

${ }^{9}$ Xavier, 'Rapid Assessment of Refugee Education in Kampala With a Focus on Access to Primary and Secondary Education amongst Congolese Refugees' Report (Kampala, 2012).

10 Rocco MacChiavello, 'Financial Development and Vertical Integration: Theory and Evidence', Journal of the European Economic Association, 10.2 (2012), 35 <https://doi.org/10.1111/j.1542-4774.2011.01042.x>. 
caused by some factors. ${ }^{11}$ The major ones are the lack of interest, failure to integrate with the new life-settings, early marriage, unwanted pregnancy, hidden costs of school, and language barriers.

This study uses descriptive and correlation research designs with data collection methods of both qualitative and quantitative research. The descriptive work explains the core reason for school dropout among Congolese Muslim refugees. We also use correlation design to determine the relationship between the various causes of school dropouts in Katwe village. Finally, the qualitative method is used to explain the views, opinions, feelings, and suggestions of the respondents. The primary data are collected by using a questionnaire distributed to 144 respondents through random sampling. We used random sampling techniques to select 144 respondents from the available 226 parents from 226 households. This will give each parent an equal chance to participate in the study. We also use the purposive sampling technique by collecting data from one parent from each of the 144 selected households. This will ensure that the data is only collected from the intended respondents and views of the households are not mixed by involving more than one respondent in each household.

This research was guided by the following questions: (1) How do language barriers cause school dropout among Congolese Muslim refugees in Katwe? (2) How does early marriage cause school dropout among Congolese Muslim refugees in Katwe? (3) How do hidden costs cause school dropout among Congolese Muslim refugees in Katwe?

\section{The Islamic Historical Context of Uganda}

The first Muslims to come to Uganda arrived in 1844 at the palace of King Ssuuna II Kalema Kisinjo (d. 1856) of the Kingdom of Buganda (d. 1856) (Kasozi 1986, 1996). These Muslims were Arab traders who hailed from the Arabian Peninsula and elsewhere, whose main goal was to pursue trade and profits; their priority goals were not to spread Islam. While King Ssuna showed interest in Islam, it was his son and successor, King Mutesa I (d. 1884), who embraced Islam and ordered the teaching of its doctrines in the palace (Kulumba n.d.). The first group of Christian missionaries arrived in Uganda in 1877 and introduced their faith to the king. There was a standoff between the King and some Muslims at the time, who insisted he must be circumcised. But because Buganda customs stipulated that a king should not be able to spill his blood freely, he preferred to follow Christianity because it did not require that he be circumcised. ${ }^{12}$

\section{Current Studies about School Dropout Rates among Refugees}

Table 1. Shows the previous research done related to our research.

Table 1. Current Studies

\begin{tabular}{|c|c|c|}
\hline Author & Topic & Objective \\
\hline $\begin{array}{l}\text { Al- } \\
\text { Hroub }\end{array}$ & $\begin{array}{l}\text { An ethnographic } \\
\text { study on dropout } \\
\text { in Palestinian } \\
\text { refugee camps in } \\
\text { Lebanon. }\end{array}$ & $\begin{array}{l}\text { Explores the } \\
\text { perspectives of } \\
\text { students, } \\
\text { administrators, } \\
\text { teachers, and } \\
\text { parents on the } \\
\text { UNRWA school } \\
\text { dropout rates in } \\
\text { Palestinian refugee } \\
\text { camps in } \\
\text { Lebanon. }{ }^{13}\end{array}$ \\
\hline
\end{tabular}

11 Jessica Norah Aguti, Dorothy Nakibuuka, and Richard Kajumbula, 'Determinants of Student Dropout from Two External Degree Programmes of Makerere University, Kampala, Uganda', Malaysian Journal of Distance Education, 11.2 (2009), 13-33; Quentin Wodon, Minh Cong Nguyen, and Clarence Tsimpo, 'Child Marriage, Education, and Agency in Uganda', Feminist Economics, 22.1 (2016), 54-79 .
${ }^{12} \mathrm{Ahmad}$ K. Sengendo, 'Islamic University in Uganda: Its Role in the Socioeconomic Development of East Africa's Muslim Communities', Muslim Institutions of Higher Education in Postcolonial Africa, 12.3 (2016), 121-33 <https://doi.org/10.1057/9781137552310_8>.

${ }^{13}$ Anies Al-Hroub, 'Perspectives of School Dropouts' Dilemma in Palestinian Refugee Camps in Lebanon: An Ethnographic Study', International Journal of 


\begin{tabular}{|c|c|c|}
\hline Author & Topic & Objective \\
\hline Adelman & $\begin{array}{l}\text { School dropout } \\
\text { in Central } \\
\text { America and the } \\
\text { promising } \\
\text { interventions } \\
\text { proposed. }\end{array}$ & $\begin{array}{l}\text { Analyzes } \\
\text { secondary school } \\
\text { dropout in Central } \\
\text { America. }{ }^{14}\end{array}$ \\
\hline $\begin{array}{l}\text { Andrei } \\
\text { et al }\end{array}$ & $\begin{array}{l}\text { Characteristics } \\
\text { and causes of } \\
\text { school dropout in } \\
\text { the European } \\
\text { Union. }\end{array}$ & $\begin{array}{l}\text { Analyzes the } \\
\text { differences } \\
\text { between EU } \\
\text { countries } \\
\text { concerning rates of } \\
\text { school dropout. }^{15}\end{array}$ \\
\hline Suárez & $\begin{array}{l}\text { Risk factors for } \\
\text { school dropout in } \\
\text { a sample of } \\
\text { juvenile offenders } \\
\text { in Asturias } \\
\text { (Spain). }\end{array}$ & $\begin{array}{l}\text { Examines the } \\
\text { relation between } \\
\text { various } \\
\text { contributing } \\
\text { factors for school } \\
\text { dropout: individual } \\
\text { factors (i.e. defiant } \\
\text { attitude, } \\
\text { irresponsibility, } \\
\text { alcohol abuse, and } \\
\text { illegal drug use), } \\
\text { family factors (i.e. } \\
\text { absent educational } \\
\text { figure and parental } \\
\text { monitoring), and } \\
\text { school factors (i.e. } \\
\text { truancy and school } \\
\text { conflict). }{ }^{6}\end{array}$ \\
\hline Dockery & $\begin{array}{l}\text { School dropout } \\
\text { indicators, trends, } \\
\text { and interventions } \\
\text { for school } \\
\text { counselors in } \\
\text { USA. }\end{array}$ & $\begin{array}{l}\text { Provides } \\
\text { information } \\
\text { regarding dropout } \\
\text { prevention and } \\
\text { how counselors } \\
\text { might best be } \\
\text { involved in this } \\
\text { important effort. }{ }^{17}\end{array}$ \\
\hline
\end{tabular}

\section{Causes of Student's Dropout among} Congolese Muslim Refugees

Stressful circumstances within the school setting will result in negative repercussions that often lead to dropout. These include exams, rules on performance and discipline, and even the effects of bad behavior. Students, however, may drop out when factors outside the school setting discourage them from completing their education. ${ }^{18}$ For boys $(26.6 \%)$ the second most cited explanation, parental indifference, is three times more likely to be cited than by girls $(8.0 \%)$. On the other hand, a comparable proportion $(14 \%)$ of boys and girls cited high schooling costs as being the reason why they stop attending school ${ }^{19}$.

\section{Language Barrier}

Language barriers appear to be one of the most difficult problems for foreign students in the Katwe area, such as Congolese Muslim refugees. ${ }^{20}$ Most second-language learners are worried that they do not have a good enough command of the language to express themselves and fear that if they attempt to communicate with others using the new language, they will be mocked ${ }^{21}$. This situation can cause considerable emotional stress and can interfere with learning with some opting to discontinue altogether. ${ }^{22}$ Students experience higher rates of failure in school if the language they learn at school is different from what they speak at home. This situation applies more
Educational Development, 35.October (2014), 53-66 $<$ https://doi.org/10.1016/j.ijedudev.2013.04.004>.

${ }^{14}$ Melissa Adelman, 'School Dropout in Central America and Promising Interventions', Report (Toronto, 2016).

15 Tudorel Andrei, Daniel Teodorescu, and Bogdan Oancea, 'Characteristics and Causes of School Dropout in the Countries of the European Union', Procedia - Social and Behavioral Sciences, 28 (2011), 328-32 $<$ https://doi.org/10.1016/j.sbspro.2011.11.062>.

16 <https://doi.org/10.3389/fpsyg.2016.01993>.

17 Donna J Dockery, 'School Dropout Indicators, Trends, and Interventions for School Counselors Donna J. Dockery', Paper (Virginia Commonwealth University', 2018).
${ }^{18}$ Jonathan Jacob Doll, Zohreh Eslami, and Lynne Walters, 'Understanding Why Students Drop out of High School, According to Their Own Reports: Are They Pushed or Pulled, Or Do They Fall out? A Comparative Analysis of Seven Nationally Representative Studies', SAGE Open, $\quad 3.4 \quad$ (2013) <https://doi.org/10.1177/2158244013503834>.

${ }^{19}$ Depio.

${ }^{20}$ Elmira R. Ibragimova and Ayziryak N. Tarasova, 'Language-Related Problems of International Students of Elabuga Institute of Kazan Federal University', Espacios, 39.2 (2018), 12.

${ }^{21} \mathrm{~J}$ Henderson and $\mathrm{J}$ Wellington, 'Lowering the Language Barrier in Learning and Teaching Science', School Science Review, 79.288 (1998), 35-46.

22 Pascoe, Hetrick, and Parker. 
acutely to forced migrants and refugees, leading many of them to drop out. ${ }^{23}$ In 2008, the United Nations Educational, Scientific and Cultural Organization (UNESCO) researched 26 countries showing that over $50 \%$ of students dropping out of school do not speak the same language as the one used at school. The language barrier is a major obstacle to the development of interpersonal trust. ${ }^{24}$ Other hand-held refugees' educational access and achievement are seldom monitored by national monitoring systems, ensuring that children and youth refugees are not only marginalized, but their educational needs and achievements other hand-held refugees remain largely invisible. ${ }^{25}$

\section{Young Marriages}

Globally, child marriage is considered a major barrier to the retention of girls in school. ${ }^{26}$ The majority of evidence available on this topic comes from Sub-Saharan Africa, particularly those looking at early pregnancy. ${ }^{27}$ The parents explain that early marriage is closely linked to income rates before they were displaced, ${ }^{28}$ that is to say, those with higher salaries prefer to get married later. However, in Uganda, early marriage is usually conducted as a hasty response to sexual intercourse. Historically, many girls end up getting married at a much younger age than the average age. ${ }^{29}$ This same phenomenon is now happening to the second generation of Congolese refugees, especially given the prolonged nature of displacement.

${ }^{23}$ D.S. Strickland and S. Riley-Ayers, 'Early Literacy: Policy and Practice in the Preschool Years', Preschool Policy Brief, 10 (2006), 1-10. Kathryn Lindholm-Leary and Ana Hernández, 'Benefits of Language Immersion Academic and Educational', Journal of Multilingual and Multicultural Development, $\quad 32.6 \quad$ (2011), 531-45 <https://doi.org/10.1080/01434632.2011.611596>.

${ }^{24}$ Benjamin Bader, Tassilo Schuster, and Anna Katharina Bader, Expatriate Management: Transatlantic Dialogues, Expatriate Management: Transatlantic Dialogues, 21 (2016) < https://doi.org/10.1057/978-1-137-57406-0>.

${ }^{25}$ Refugee Education Team, Missing Out Refugee Education', Report (UK, 2016).
Extreme deprivation, abuse, and sexual violence threats frequently discourage girls from going to school, making them more vulnerable to sexual and other types of violence in and around their homes and fields. With no other economic options and no reliable way to defend girls against attack and abuse, parents and young women often see no alternative than to arrange early marriages. But this in itself may reflect a type of abuse, contributing to early childbearing ill-health and continued impoverishment compounded by the denial of educational opportunities.

Young marriages often correlate with other factors, such as the household characteristics, the effect of family and school climate on education, sexual and reproductive health behavior, and normative attitudes about gender.

Background Characteristics: According to the Xavier project, socio-economic and sociodemographic characteristics of the household are linked to both early marriage and school dropout in the life of refugees. It covers deprivation, the level of education of parents, and whether or not violence has impacted the refugee. Furthermore, dropout is often associated with the death of a parent or living with a single mother. (July 2012)

For some parents, the marriage of girls is not an inappropriate practice because it is difficult for them to ensure the security of their children in the slum areas during adolescence. It is believed that girls are better off when they marry as soon as they find someone they love.

${ }^{26}$ Kazutaka Sekine and Marian Ellen Hodgkin, 'Effect of Child Marriage on Girls' School Dropout in Nepal: Analysis of Data from the Multiple Indicator Cluster Survey 2014', PLoS ONE, 12.7 (2017), 1-13 <https://doi.org/10.1371/journal.pone.0180176>.

27 Jenny Birchall, 'Early Marriage , Pregnancy and Girl Child School Dropout', Knowledge, Evidence and Learning for Development, 2.7 (2018), 1-15.

${ }^{28} \mathrm{~N}$ Gottschalk, 'Uganda: Early Marriage as a Form of Sexual Violence', Forced Migration Review (Uganda, 2007).

${ }^{29}$ UNICEF, 'Ending Child Marriage and Teenage Pregnancy in Uganda', Kampala: United Nations Children's Fund Uganda Country Office, 2015. 
The common reason is to avoid the pain of seeing their daughters bring their grandchildren out of their father's house, where it's hard to even find a living. where even finding a living is difficult. Teen pregnancy leads to health issues and negative social outcomes for both teen mothers and their children ${ }^{30}$.

\section{Hidden School Fees}

Some also attribute the high school dropout in Uganda to the hidden costs of compulsory education. Families are expected to contribute to school meals, scholastic supplies, and uniforms under the government's Universal Primary Education (UPE). It can be difficult for many children from disadvantaged families to complete the seven-year cycle.

In Kampala, UNHCR is dependent on its implementing partner, Inter Aid Uganda (IAU), to take the lead in ensuring that refugee children attend school in Kampala's Muslim areas. Their advocacy work with refugees and their cooperation with the Kampala City Council Authority (KCA) in implementing the government's Universal Primary Education (UPE) system has been a major part of their success in bringing children to schools. To date, 56 primary schools have been identified in Kampala and are receiving children from refugee communities. IAU offers minimal content and technical assistance, and also maintains records of those children attending primary school registered with refugee families. No information is available about refugee families living in Kampala who are self-reliant and are responsible for educating their children. In addition, there is no formal education and knowledge management program in place to provide information and documents on the scope and quality of other educational levels, such as early childhood, secondary and postsecondary education for refugees living in Kampala. It is therefore difficult to claim that refugee education in Kampala is adequately provided for this population. ${ }^{31}$

Islamic family background is widely acknowledged as the single most significant contributor to school success. ${ }^{32}$ Socioeconomic status most generally calculated by parental education and family income is a strong predictor of school achievement and dropout activity. ${ }^{33}$ Parental education affects the expectations and educational interest of the students; while family income allows parents to support their children's education, including access to better-quality schools, after-school and summer-school programs, and home-based learning support. Furthermore, students whose parents track and control their behaviors are less likely to drop out of school, provide emotional support, promote autonomous decision-making (known as authoritarian parenting style), and are generally more involved in their education. Additionally, singleparent and step-family students are more likely to drop off from school than students in twoparent families. It is commonly accepted that schools, particularly dropout rates, have a tremendous impact on student achievement. ${ }^{34}$
${ }^{30}$ Molly Rosenberg and others, 'Relationship between School Dropout and Teen Pregnancy among Rural South African Young Women', International Journal of Epidemiology, 44.3 (2015), 928-36 <https://doi.org/10.1093/ije/dyv007>.EmilyRuedinger and Joanne E. Cox, 'Adolescent Childbearing: Consequences and Interventions', Current Opinion in Pediatrics, $\quad 40.1 \quad$ (2012), 446-52 <https://doi.org/10.1097/MOP.0b013e3283557b89>.

${ }^{31}$ Stephen Odebero, Improving The Quality of Education for Children Living in Urban Informal Settlements in Uganda as Part of The East African
Community Initiative', Kenya Journal of Educational Planning Economics and Management, 14. 1 (2019), 181-203.

32 William Sander, 'Religious Background and Educational Attainment: The Effects of Buddhism, Islam, and Judaism', Economics of Education Review, 29.3 (2010), 489-93.

${ }^{33} \mathrm{R}$. W. Rumberger, 'The Economics of High School Dropouts', International Encyclopedia of Education, 20 (2010), 325-30 <https://doi.org/10.1016/B978-0-08044894-7.01223-9>.

34 Elizabeth Glennie and others, 'Addition by Subtraction: The Relation between Dropout Rates and 
Schools with better student achievement usually have a low dropout rate of students, and vice versa.

\section{The Solution to School Dropout}

The following are feasible solutions to the problem of school dropout. Recommendation 1, track the progress of all students and interfere proactively when students display early signs of non-attendance and conduct or academic problems. ${ }^{35}$ Phase 1: Organize and analyze data to identify students who are missing school, having behavioral problems, or struggling in their classes; Phase 2: Involve students who display early signs of getting derailed from participation and attendance; Phase 3: If data show high absenteeism rates, take steps to help students, parents and school employees understand the importance of daily school attendance; Phase 4: Track progress and tailor interventions as needed. Recommendation 2, provide comprehensive, individualized assistance to students who have fallen off track and are facing major learning challenges; Phase 1: Assign a single person to be the primary advocate for each student identified as need in individualized support. Phase 2: Create a help menu that advocates may use to assist students. Phase 3: Help advocates with ongoing professional development programs and resources to track their work.

Recommendation 3, engage students by providing curricula and services that link schoolwork to college and career success and strengthen the ability of students to handle challenges inside and outside of school. Phase 1: Connect schoolwork directly to the options available for students after graduating from high school; Phase 2: Include curricula and services to help students develop relationships of support and teach students how to cope with challenges; Phase 3: periodically review student engagement in identifying areas for change and recommend strategies for students who are not substantially involved.

Recommendation 4, create small, personalized communities for schools with many at-risk students to facilitate monitoring and support. Phase 1: Determine whether there should be a single or multiple grades serving local communities; Phase 2: Build teacher teams that share popular student groups; Phase 3: Identify a theme to help build a strong sense of identity and community and improve engagement among students; Phase 4: Create a schedule including specific planning times and adequate staff opportunities to track and help students.

\section{Data Analysis of Student Dropout Research}

Data processing is the stage where a researcher organizes or transforms the gathered data into tables or figures, while data analysis is a process of categorizing, ordering, manipulating, breaking down, and summarizing data to obtain answers to the research questions. Due to the time constraint of data collection, Google form was used. After obtaining the data, we cleaned them up by removing noise and checking for missing data, before refilling them again. Later data analysis was done in two stages namely. This stage involves firstly the process of editing: Detecting and eliminating errors and keeping them to a minimum in the completed questionnaire. This will help the researcher to check for completeness of the questionnaire in answering the question. Secondly, central editing: This is employed when the entire questionnaire is completed, errors are detected, such as errors when entering information in the wrong places, numerical error, and the correct answer is subsequently given by reviewing the
School-Level Academic Achievement', Teachers College Record (1970), 114.8 (2012), 1.
${ }^{35} \mathrm{R}$ Rumberger and others, 'Preventing Dropout in Secondary Schools', National Center for Educational Evaluation and Regional Assistance, 31.1 (2017), 1-97. 
information that is required in the schedule. Table 2 shows the level of the Likert scale.

Table 2. Level of Likert Scale on Respondents

\begin{tabular}{lcccc}
\hline $\begin{array}{l}\text { Descrip } \\
\text { tion }\end{array}$ & $\begin{array}{l}\text { Sym- } \\
\text { bol }\end{array}$ & Points & $\begin{array}{c}\text { Average } \\
\text { /mean }\end{array}$ & $\begin{array}{l}\text { Interpre- } \\
\text { tation }\end{array}$ \\
\hline $\begin{array}{l}\text { Strongly } \\
\text { Agree }\end{array}$ & SA & 4 & $\begin{array}{c}3.21- \\
4.00\end{array}$ & Majority \\
\hline Agree & A & 3 & $\begin{array}{c}2.41- \\
3.20\end{array}$ & Many \\
\hline Disagree & D & 2 & $1.61-$ & Few \\
& & & 2.40 & \\
\hline Strongly & SD & 1 & $0.8-1.60$ & Very few \\
Disagree & & & & \\
\hline
\end{tabular}

Coding: This is the process of assigning numerals or other symbols to answers the question "what?". This was done so that responses would be able to be put into a limited number of classes and categories. We achieved this by coding the answer from the questionnaire.

Classification: this is a stage of storing the data by grouping them. This was done according to the data characteristics whereby each attribute was saved independently. Another stage is tabulation: This involves the data being arranged in a logical order for statistical analysis. We carry this out after sorting the data. Once we know the number of tables required, the data will be analyzed using SPSS as shown in Table 2. Level of Likert Scale.

We also used Statistical Package for Social Scientists (SPSS) because it can perform complex data manipulation and analysis and has a lot of statistical and mathematical function scores of statistical data handling capability.

Thus, respondents' demographic information will be analyzed using descriptive statistics, the information of which was converted into frequency and percentage tables. Objectives 1 and 2 were analyzed using descriptive statistics, whose quantitative objective data was converted to frequency and percentage, Mean and Standard Deviation tables, while objective 3 and the assumption were determined using inferential statistics by running Pearson's moment of correlation.

\section{Results of Student Dropout Research Respondents' Demographic Information}

The study assessed the respondents' biodata in terms of gender, age, marital status, occupation, and level of education. The purpose of studying the biodata of respondents was to find out whether there were any variations in the respondents' background and whether these had effects on the respondents' responses to "what?". The result of the demographic data can be found in Table 3 .

Table 3. Demographics Data of Respondents

\begin{tabular}{llcc}
\hline \multicolumn{2}{c}{ Respondents } & Frequency & Percentage \\
\hline Gender & Male & 67 & 47.5 \\
& Female & 74 & 52.5 \\
\hline Age & $18-25$ & 60 & 42.6 \\
& $26-35$ & 53 & 37.6 \\
& $36 \quad$ and & 28 & 19.9 \\
& above & & \\
\hline Marital & Single & 60 & 42.6 \\
status & Married & 49 & 34.8 \\
& Divorced & 16 & 11.3 \\
& Separated & 16 & 11.3 \\
& & & \\
\hline Occupation & Employed & 25 & 17.7 \\
& Not & 50 & 35.5 \\
& employed & 64 & 45.4 \\
& Self- & & \\
& employed & & 7.8 \\
\hline Education & Primary & 11 & 31.9 \\
& Secondary & 45 & 21.3 \\
& College & 30 & 39.0 \\
\hline & University & 55 & \\
\hline
\end{tabular}

Table 3. shows that $67(47.5 \%)$ of the respondents were male. This means that the views of females are dominant. It also shows the age of the respondents, whereby $60(42.6 \%)$ were aged between 18 - 25 years; 53 (37.6\%) were aged between $26-35$ years, and 28 (19.9\%) were 36 years and above. The table also shows the marital status of the respondents: we found that $60(42.6 \%)$ were single; the married population 
was 49 (34.8\%); the divorced were $16(11.3 \%)$, and the separated were $16(11.3 \%)$. The above table also shows the occupation of the respondents: $64(45.4 \%)$ are self-employed; 50 $(35.5 \%)$ are unemployed, and $25(17.7 \%)$ are employed. This clearly shows that a large number of Congolese Muslim refugees of Katwe are self-employed. Last but not least, the above table shows the education level of the respondents: $55(39.0 \%)$ have completed university education; $30(21.3 \%)$ graduate from college; 45 (31.9\%) completed secondary level, and $11(7.8 \%)$ is the primary school graduation. This shows that the majority are educated.

Table 4. How Hidden Costs Cause School Dropout

\begin{tabular}{lccc}
\hline Indicators & Mean & SD & $\begin{array}{l}\text { Interpre- } \\
\text { tation }\end{array}$ \\
\hline $\begin{array}{l}\text { UPE schools are charging } \\
\text { fees. }\end{array}$ & 2.8440 & .79538 & Many \\
\hline
\end{tabular}

If parents do not make a financial contribution to government schools, their $\begin{array}{llll}2.8936 & .83411 & \text { Many }\end{array}$ children are driven out.

\begin{tabular}{lllll}
\hline $\begin{array}{l}\text { Fees are charged } \\
\text { specifically to refugees. }\end{array}$ & 2.7376 & .94601 & Many \\
\hline $\begin{array}{l}\text { Parents/guardians are not } \\
\text { able to contribute to the } \\
\text { education of children. }\end{array}$ & 3.1135 & .86266 & Many \\
\hline $\begin{array}{l}\text { School fees are too high. } \\
\text { Hidden costs. }\end{array}$ & 3.2482 & .79423 & Many \\
\hline \multicolumn{1}{c}{ Valid N (listwise) } & & & \\
\hline
\end{tabular}

Language Barriers Cause School Dropout among Congolese Refugees in Katwe, Kampala, Uganda

The first objective of the study was to find out how language barriers cause school dropout among Congolese Muslim refugees in the Katwe village. The findings are presented in the subsection of the report.
Table 5. Establish How Language Barriers Cause School Dropout among Congolese Refugees

\begin{tabular}{|c|c|c|c|}
\hline Indicators & Mean & SD & $\begin{array}{l}\text { Inter- } \\
\text { pre- } \\
\text { tation }\end{array}$ \\
\hline $\begin{array}{l}\text { Children dropping out } \\
\text { because of language barriers } \\
\text { at school. }\end{array}$ & 2.9291 & 85059 & Many \\
\hline $\begin{array}{l}\text { Refugees are asked to enroll } \\
\text { in lower grades compared to } \\
\text { their class they were in when } \\
\text { in Congo. }\end{array}$ & 3.0426 & 73555 & Many \\
\hline $\begin{array}{l}\text { Free language literacy is } \\
\text { being provided by } \\
\text { nongovernmental } \\
\text { organizations. }\end{array}$ & 2.9007 & 84773 & Many \\
\hline $\begin{array}{l}\text { Accelerated learning is being } \\
\text { provided by refugee charity } \\
\text { organizations to boost the } \\
\text { education environment. }\end{array}$ & 3.1915 & 73596 & Many \\
\hline $\begin{array}{l}\text { School becomes difficult } \\
\text { when students who have } \\
\text { been studying in French are } \\
\text { now shifting to English. }\end{array}$ & 3.2979 & 85977 & Majority \\
\hline Language & 3.0723 & .54525 & \\
\hline
\end{tabular}

Table 5 shows the results of how early marriages cause dropout among Congolese Muslim refugees in Katwe. The findings show the average mean of 3.2184 and the standard deviation of .56310 . This means that early marriages cause the majority of dropout cases. The findings agree with Xavier project, which showed that that refugees' socio-economic and socio-demographic characteristics are associated with both early marriage and school dropout. Our finding generated a mean of 3.0213 and an SD of .83211 the study agree with Inter Aid, a refugee based organization, which reported that for some parents marriage of girls is not an inappropriate practice because it is difficult for them to ensure the security of their children in the slum areas. "It is better for them to get married as soon as they can find someone they love and live a happy life. This avoids the pain of seeing them bringing grandchildren in this family where even finding a living is difficult. 
How Hidden Costs at School Causes Dropouts among Congolese Muslim Refugees in Katwe

Objective three of the study was to examine how hidden costs at school cause dropout among Congolese Muslim refugees in Katwe. Many parents are told that education is free but after taking their children to school they come to realize that, their children are sent away. The finding shows the average mean of 2.9674 and the SD of .58438. This means that many children drop out of school because their parents, being refugees, are not able to pay the fees. These findings agree with The New Vision news article of November 10, 2012, which reports how critics have attributed high school dropout rates in Uganda to the hidden cost of universal education for poor families and forced migrants, many of whom may find it hard to complete the seven-year cycle of primary education.

Our findings generated the mean of 3.2482 and the SD of .79423. This means that the money charged is too high for guardians or parents to be able to raise. This leads to high dropout cases. This supports the argument that it is difficult to defend the view that education is being adequately provided for the refugee population in Kampala.

To Determine the Relationship between the Causes of School Dropout and the Actual School Dropout

Objective four was to determine the relationship between the above-mentioned causes of school dropout and the actual school dropout. The variable investigated was the causes of school dropout. Our findings are revealed in the subsection of the study.

Our findings show a mean of 3.2482 and an SD of .79423. This means that the fees charged are too high for many guardians/parents, which leads to many dropout cases. This supports previous studies that argue that it is difficult to accept the claim that education is being adequately provided for the refugee population in Kampala.
Table 6. The Correlation between Causes of School Dropout and the Actual School Dropout

\begin{tabular}{lcc}
\hline Analysis & $\begin{array}{l}\text { Causes of } \\
\text { School } \\
\text { Dropout }\end{array}$ & $\begin{array}{l}\text { Actual School } \\
\text { Dropout }\end{array}$ \\
\hline Pearson Correlation & 1 & $.502^{* *}$ \\
\hline Sig. (2-tailed) & 141 & .000 \\
\hline $\mathrm{N}$ & $.502^{* *}$ & 141 \\
\hline Pearson Correlation & .000 \\
\hline Sig. (2-tailed) & 141 \\
\hline $\mathrm{N}$ & 141 \\
\hline$* *$ Correlation is significant at the 0.01 level (2- \\
tailed).
\end{tabular}

Table 6 shows that the alpha-value is 0.01 and the $\mathrm{P}$-value is .502. If the $\mathrm{P}$-value is less than the alpha-value we should reject the hypothesis and accept the alternative hypothesis. It was hypothesized that there is no relationship between the causes of school dropout and the actual school dropout among Congolese Muslim refugees in Katwe, Kampala, Uganda.

\section{Conclusion}

This study was based on a general objective which was to find out the causes of school dropout among Congolese Muslim refugees in Katwe, Kampala, Uganda. The findings show that the lack of information about school fees, early marriage practices, and language barriers are the majors causes explaining why many refugees opt to drop out of school. Therefore, the hypothesis of our study that the school dropout rate has a relation with the real-life challenges faced by refugees is correct. Furthermore, this study focused on how to minimize the challenges faced by refugees to ensure that they can gain the solid education needed for a brighter future. Lastly, the Muslim community in Uganda should support refugees by providing for their basics needs. They should also offer Coroahan studies and lessons on the Arabic language to strengthen their faith and giving them hope in the future. 
Based on our findings above, we recommend that the UNHCR and its stakeholders in collaboration with the Ministry of Education and Sports of Uganda need to begin employing refugees that have qualifications to work in public institutions. This is to ensure that the refugees may influence the decision-making process because some school directors may not favor the refugees.

There is a need not only to sensitize the parents but to also give a message of hope to the refugee community. Being a refugee does not spell the end of life, but can be the beginning of a better future. Hence, the refugee community must be counseled on this matter and be encouraged to be self-reliant, hardworking, and optimistic.

\section{References}

\section{Journals}

Aguti, Jessica Norah, Dorothy Nakibuuka, and Richard Kajumbula, 'Determinants of Student Dropout from Two External Degree Programmes of Makerere University, Kampala, Uganda', Malaysian Journal of Distance Education, 11.2 (2009), 13-33

Al-Hroub, Anies, 'Perspectives of School Dropouts' Dilemma in Palestinian Refugee Camps in Lebanon: An Ethnographic Study', International Journal of Educational Development, 35.October (2014), 53-66

$<$ https://doi.org/10.1016/j.ijedudev.201 3.04.004>

Andrei, Tudorel, Daniel Teodorescu, and Bogdan Oancea, 'Characteristics and Causes of School Dropout in the Countries of the European Union', Procedia - Social and Behavioral Sciences, 28 (2011), 328-32

$<$ https://doi.org/10.1016/j.sbspro.2011. $11.062>$

Birchall, Jenny, 'Early Marriage, Pregnancy and Girl Child School Dropout', Knowledge, Evidence and Learning for Development, 2.7 (2018), 1-15
Depio Shiela, Ahaibwe Gemma, Kasirye Ibrahim, Nandy Shailen, Pomati Marco, 'Child Poverty and Deprivation in Areas Evidence from Uganda', Eprc, 2018, 12-14

Doll, Jonathan Jacob, Zohreh Eslami, and Lynne Walters, 'Understanding Why Students Drop out of High School, According to Their Own Reports: Are They Pushed or Pulled, Or Do They Fall out? A Comparative Analysis of Seven Nationally Representative Studies', SAGE Open, $\quad 3.4$

<https://doi.org/10.1177/215824401350 $3834>$

Earle, Alison, Natalia Milovantseva, and Jody Heymann, 'Is Free Pre-Primary Education Associated with Increased Primary School Completion? A Global Study', International Journal of Child Care and Education Policy, 12.1 (2018), 13

Fernández-Suárez, Asunción, Juan Herrero, Beatriz Pérez, Joel Juarros-Basterretxea, and Francisco J. Rodríguez-Díaz, 'Risk Factors for School Dropout in a Sample of Juvenile Offenders', Frontiers in Psychology, 7.DEC (2016), 1-7 <https://doi.org/10.3389/fpsyg.2016.01 993>

Glennie, Elizabeth, Kara Bonneau, Michelle Vandellen, and Kenneth A Dodge, 'Addition by Subtraction: The Relation between Dropout Rates and School-Level Academic Achievement', Teachers College Record (1970), 114.8 (2012), 1

Henderson, J, and J Wellington, 'Lowering the Language Barrier in Learning and Teaching Science', School Science Review, 79.288 (1998), 35-46

Ibragimova, Elmira R., and Ayziryak N. Tarasova, 'Language-Related Problems of International Students of Elabuga Institute of Kazan Federal University', Espacios, 39.2 (2018)

Lindholm-Leary, Kathryn, and Ana Hernández, 'Benefits of Language Immersion Academic and Educational', Journal of Multilingual and Multicultural Development, 32.6 (2011), 531-45 
$<$ https://doi.org/10.1080/01434632.201 $1.611596>$

MacChiavello, Rocco, 'Financial Development and Vertical Integration: Theory and Evidence', Journal of the European Economic Association, $10.2 \quad$ (2012), 35 $<$ https://doi.org/10.1111/j.15424774.2011.01042.x>

Odebero, Stephen, 'Improving the Quality of Education for Children Living in Urban Informal Settlements in Uganda as Part of the East African Community Initiative', Kenya Journal of Educational Planning Economics and Management, 14. 1 (2010), 181-203

Pascoe, Michaela C., Sarah E. Hetrick, and Alexandra G. Parker, 'The Impact of Stress on Students in Secondary School and Higher Education', International Journal of Adolescence and Youth, 25.1 (2020), 10412

$<$ https://doi.org/10.1080/02673843.201 9.1596823>

Rosenberg, Molly, Audrey Pettifor, William C. Miller, Harsha Thirumurthy, Michael Emch, Sulaimon A. Afolabi, and others, 'Relationship between School Dropout and Teen Pregnancy among Rural South African Young Women', International Journal of Epidemiology, 44.3 (2015), 928-36 <https://doi.org/10.1093/ije/dyv007>

Ruedinger, Emily, and Joanne E. Cox, 'Adolescent Childbearing: Consequences and Interventions', Current Opinion in Pediatrics, 24.4 (2012), 446-52 <https://doi.org/10.1097/MOP.0b013e3 283557b89>

Rumberger, R. W., 'The Economics of High School Dropouts', International Encyclopedia of Education, 2010, 325-30 <https://doi.org/10.1016/B978-0-08044894-7.01223-9>

Rumberger, R, H Addis, E Allensworth, R Balfanz, D Duardo, and M Dynarski, 'Preventing Dropout in Secondary Schools', National Center for Educational Evaluation and Regional Assistance, 2017, 197
Sander, William, 'Religious Background and Educational Attainment: The Effects of Buddhism, Islam, and Judaism', Economics of Education Review, 29.3 (2010), 489-93

Sekine, Kazutaka, and Marian Ellen Hodgkin, 'Effect of Child Marriage on Girls' School Dropout in Nepal: Analysis of Data from the Multiple Indicator Cluster Survey 2014', PLOS ONE, 12.7 (2017), 1-13 $<$ https://doi.org/10.1371/journal.pone.0 180176>

Sengendo, Ahmad K., 'Islamic University in Uganda: Its Role in the Socioeconomic Development of East Africa's Muslim Communities', Muslim Institutions of Higher Education in Postcolonial Africa, 2016, 121-33 $<$ https://doi.org/10.1057/978113755231 0_8>

Strickland, D.S., and S. Riley-Ayers, 'Early Literacy: Policy and Practice in the Preschool Years', Preschool Policy Brief, 10 (2006), 1-10

Wagner, Daniel A, What Happened to Literacy? Historical and Conceptual Perspectives on Literacy in UNESCO', International Journal of Educational Development, 31.3 (2011), 319-23

Wodon, Quentin, Minh Cong Nguyen, and Clarence Tsimpo, 'Child Marriage, Education, and Agency in Uganda', Feminist Economics, 22.1 (2016), 54-79

\section{Reports and paper}

Adelman, Melissa, 'School Dropout in Central America and Promising Interventions', Report (Toronto, 2016)

Christine Mbabazi Mpyangu, et all, 'Out of School Children Study in Uganda' Paper (Kampala, <https://doi.org/10.1016/j.jiec.2016.01.0 $36>$

Bader, Benjamin, Tassilo Schuster, and Anna Katharina Bader, 'Expatriate Management: Transatlantic Dialogues', Report (UK, 2016 $<$ https://doi.org/10.1057/978-1-13757406-0>

Dockery, Donna J, 'School Dropout Indicators, Trends, and Interventions for School 
Counselors Donna J. Dockery' Paper (Virginia Commonwealth University', 2018)

Education Refugee Team, 'Missing Out Refugee Education', Report (UK, 2016)

Global Partnerhip for Education Team, Results Report 2019 (Washington D.C, 2019)

Gottschalk, N.,'Uganda: Early Marriage as a Form of Sexual Violence', Forced Migration Review (Uganda, 2007)

Sabates, Ricardo, J Westbrook, K Akyeampong, and Frances Hunt, 'School Drop out: Patterns, Causes, Changes and Policies', 'Paper prepared by the Centre for International Education School of Education and Social Work University of Sussex July 2010.
UNICEF, 'Ending Child Marriage and Teenage Pregnancy in Uganda', Report (Kampala: United Nations Children's Fund Uganda Country Office, 2015)

WHO, 'Adoscent Pregnancy', Report (Washington D.C., 2020)

Xavier, 'Rapi Assessment of Refugee Education in Kampala With a Focus on Access to Primary and Secondary Education amongst Congolese Refugees', Report (Kampala, 2012) 